\title{
Analysis and Control of Bankruptcy and Reorganization Processes: Case Studies Using Accounting Data
}

\author{
George Abuselidze ${ }^{1, *}$, and Anna Slobodianyk ${ }^{2}$ \\ ${ }^{1}$ Batumi Shota Rustaveli State University, Ninoshvili, 35, 6010, Batumi, Georgia \\ ${ }^{2}$ National University of Life and Environmental Science of Ukraine, Heroiv Oborony, 11, 03041, \\ Kiev, Ukraine
}

\begin{abstract}
The article is devoted to the justification and development of recommendations for improving the use of accounting data for the analysis and control of bankruptcy and reorganization processes of enterprises. It is determined that in conditions of financial and political instability, the activities of enterprises are accompanied by crisis situations, which may result in insolvency or bankruptcy. The peculiarities of processes of bankruptcy and reorganization of enterprises, using the methods of economic analysis, analysis of financial state and efficiency of the investigated company, as well as evaluated the effectiveness of the use of accounting data for analysis and control of processes of bankruptcy and reorganization of enterprises. Overview of cases in business practice for which the company is liquidated. The state and volume of activity of the basic enterprise in the context of the main indicators of financial statements for the last three years are analyzed. As a result of the analysis of the enterprise, it is proved that LLC Agrocomplex is profitable, with positive growth trends for most of the main indicators of economic activity. To identify signs of a crisis, the company assessed the threat of bankruptcy based on rapid diagnostics. The authors proved that the twofactor model for assessing the probability of bankruptcy of an enterprise shows that the probability of bankruptcy for LLC Agrocomplex is very low. The authors prove that when analysing the financial condition of an enterprise, a situation may arise when some indicators of the discriminant model for a particular enterprise may be very low compared to their "normal" values, and others - on the contrary, too high, which is also "bad". It is proved that their combination can indicate a stable financial condition of the enterprise, since it is the calculation of one integral indicator based on all input factors at the same time.
\end{abstract}

\section{Introduction}

Today, the work of many, even promising, companies is hindered by huge accounts payable to suppliers, the budget, and the workforce. No investor will invest money knowing that

*Corresponding author: george.abuselidze@bsu.edu.ge 
their money will be used to pay off the company's debts. The instability and crisis state of the economy negatively affects all spheres of public and economic life in Country. This period is characterized by a significant decline in production, depreciation of the national currency and a decrease in demand for products. All of the above has a negative impact on the activities of individual enterprises, most of them become insolvent and go into a deep crisis. This situation requires solving the problems of individual enterprises at the state level by using the institution of bankruptcy. Usually, the cause of a particular risk situation is understood to be some condition that causes tension. Sources of such tension can be: directly economic activity; activity of the enterprise itself; lack of information about the state of the environment that affects the final result. The search for ways to improve the health of insolvent enterprises occupies one of the leading places in modern economic practice. In Ukraine, the number of insolvent enterprises is steadily growing.

\subsection{Problem Statement}

In conditions of financial and political instability, the activities of enterprises are accompanied by crisis situations, which may result in insolvency or bankruptcy. The reason for such a situation is often mistakes in strategic plans and in a set of tactical measures that do not fully allow the company to find a successful way out of a crisis situation. If the company is threatened with bankruptcy, it can declare on its own initiative the reorganization (recovery, anti-crisis management) of the company and thus avoid unjustified bankruptcy.

The objectives of the study in accordance with these problems and the relevance of the study are:

* Determine the nature of liquidation and reasons for bankruptcy of the company;

* Research the methodology and organization of accounting for liquidation and bankruptcy operations;

* Investigate the methodology and organization of analysis of financial prerequisites for insolvency and bankruptcy of LLC Agrocomplex;

* Provide suggestions for improving accounting, analysis and control of financial processes of insolvency and bankruptcy of LLC Agrocomplex.

\subsection{Purpose of the Study}

The purpose of the study is to provide theoretical justification and develop recommendations for improving the use of accounting data for the analysis and control of bankruptcy and reorganization processes.

\section{Research Methods}

Development of private business and its protection from crisis or bankruptcy is increasingly becoming important not only for entrepreneurs, but for government as well. Causes of enterprise bankruptcy or crisis and searching ways to overcome it was the main concern of scientists and practitioners.

The research process uses the fundamental principles of economic theory, the theory of Finance and accounting, General scientific and special methods of cognition. Based on the methods of analysis and synthesis, the features of the processes of bankruptcy and reorganization of enterprises, as well as methods of economic analysis, which helped to analyse the financial condition and efficiency of the studied enterprise, as well as to evaluate the effectiveness of using accounting data for analysing and controlling the 
processes of bankruptcy and reorganization of enterprises, are studied. Abstractions, induction and deduction methods are also used to form individual conclusions.

Despite that fact that programs for overcoming bankruptcy or crisis differ from each other, we tried grouping their opinions and presented them as approaches.

According to Authors [2-5, 10, 16] Fiscal or/and monetary policy has become an important economic tool in dealing with the consequences of the crisis. The author opinion, by formation of the compensated (optimal) MP plus policy [4] government can compensate crisis between production dynamics and solvency demand. This approach provides the optimal growth of production capacity and economic activity [5].

In this paper [21], the authors propose an optimal management solution for assessing the safety of industrial enterprise development and its innovative and investment orientation in various business conditions: from stable to crisis and Vice versa.

\section{Results and Discussion}

According to the Law of Ukraine on restoring the debtor's solvency or declaring it bankrupt, bankruptcy is the inability of the debtor determined by the economic court to restore its solvency and satisfy the creditors' claims recognized by the court only through the application of a liquidation procedure.

Bankruptcy is a consequence of a deep financial crisis, a system of management measures that did not lead to positive results. A financial crisis is understood as an imbalance in the company's activities and limited opportunities for its influence on financial relations. Legal science generalizes the concept of liquidation as a procedure regulated by law, the result of which is the termination of the legal entity. So, liquidation is one of the forms of termination of a legal entity. A legal entity is liquidated by the decision of its participants or the body of the legal entity authorized to do so by the constituent documents or by a court decision.

The company is liquidated in the following cases:

1. Based on a decision made by the owner himself:

- by decision of the participants or the body of the legal entity authorized to do so by the constituent documents, that is, the highest body of the company or the head of a unitary enterprise;

- at the end of the period for which it was created, or after achieving the goal set when it was created.

2. Compulsory liquidation by court decision:

- invalidation of an entry on state registration due to violations of the law committed when creating a legal entity that cannot be eliminated;

- carrying out activities contrary to the constituent documents or prohibited by law;

- non-compliance of the minimum amount of the authorized Fund with the requirements of the law;

- failure to submit tax returns and other documents to the authorities within a year in accordance with the law;

- the presence in the Unified state register of an entry about the absence of a legal entity at the location indicated by it [17].

3. In the process of declaring an enterprise bankrupt in accordance with the Law on restoring the debtor's solvency or declaring it bankrupt [8].

Confirmed amounts of accounts payable for a period of up to three years should be repaid with funds, and in their absence-with inventory items in agreement with creditors (which will result in gross income, gross expenses, and VAT tax liabilities). For confirmed receivables, send claims to debtors, and in case of refusal to repay - claims to the arbitration 
court. Outstanding debts at the date of the liquidation balance sheet are written off in the same manner as overdue ones [19].

According to calculations with accountable persons, the amounts of accounts payable can be represented by means of funds. In the absence of money, various options are possible. If the accountable persons agree, it is possible to repay the debt with stocks. In accounting, this transaction is recorded as sales for tax purposes - as sales (which will result in gross income, gross expenses, and VAT tax liabilities).

Accounts receivable is unlikely today, since the issuance of money for the report is allowed only if the previously issued amounts are reported. However, if the amounts issued under the report are not returned, they can be withheld or deposited in the company's cash register [11].

Arrears of wages should be paid with funds, if they are not available-with inventory items at the request of employees (which will result in gross income, gross expenses, and VAT tax liabilities).

The current legislation provides for the cancellation of wage arrears only if the company is declared bankrupt in accordance with the law. However, in our opinion, even if the company is liquidated for reasons that are not related to bankruptcy, the depositor's debt and wage arrears that cannot be issued should also be attributed to income from writing off accounts payable. In the same way, deductions for social and pension insurance accrued on the amounts of the written-off salary should be deducted for income [24].

In order to draw conclusions about the state and volume of activity of the underlying enterprise, it is necessary to analyze its activities in the context of the main indicators of the financial statements for the last three years. The information base for the analysis of the company is its financial statements in the form number 1 "Balance sheet" and in the form number 2 "Report on financial results".

A graphical representation of the dynamics of the main indicators of activity of LLC Agrocomplex for 2017-2019 is shown in Fig. 1.

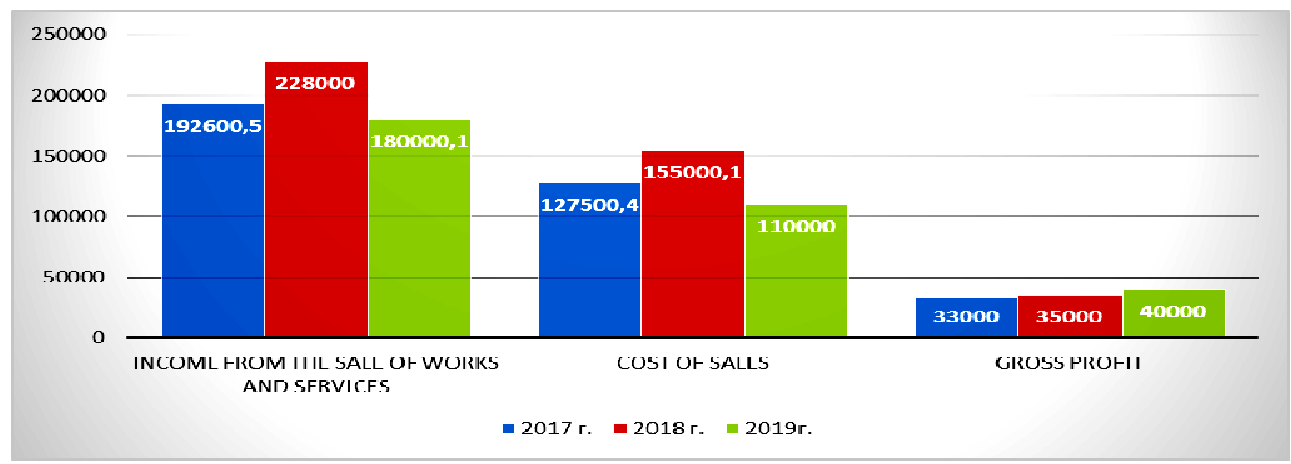

Fig. 1. Dynamics of the main performance indicators of LLC Agrocomplex for 2016-2018. Source: calculated by the authors based on data from LLC Agrocomplex.

Return on assets, calculated as the ratio of profit to the average amount of assets on annual balance sheets, tends to increase over the years from $2.8 \%$ in $2017,3.3 \%$ in 2018 and the highest return, $4.2 \%$ in 2019

So, the "Golden rule of Economics" at the enterprise is not observed, because the change in sales volume and the balance sheet currency is less than $100 \%$, but, in general, it should be concluded that the company LLC Agrocomplex is profitable, with positive growth trends for most of the main indicators of economic activity.

The purpose of assessing the financial condition of the enterprise is to find reserves to increase the profitability of production and strengthen commercial calculation as the basis 
for stable operation of the enterprise and its obligations to the budget, the Bank and other institutions.

The analysis of the financial condition of the enterprise includes following stages $[6, \mathrm{p}$. 219]: preliminary (overall) assessment of the financial condition of the company and changes in its financial indicators over the reporting period Express analysis; analysis of the structure and dynamics of assets and liabilities; analysis of liquidity and solvency of the enterprise; analysis of cash flow; analysis of financial stability; the analysis of business activity (Fig. 2).

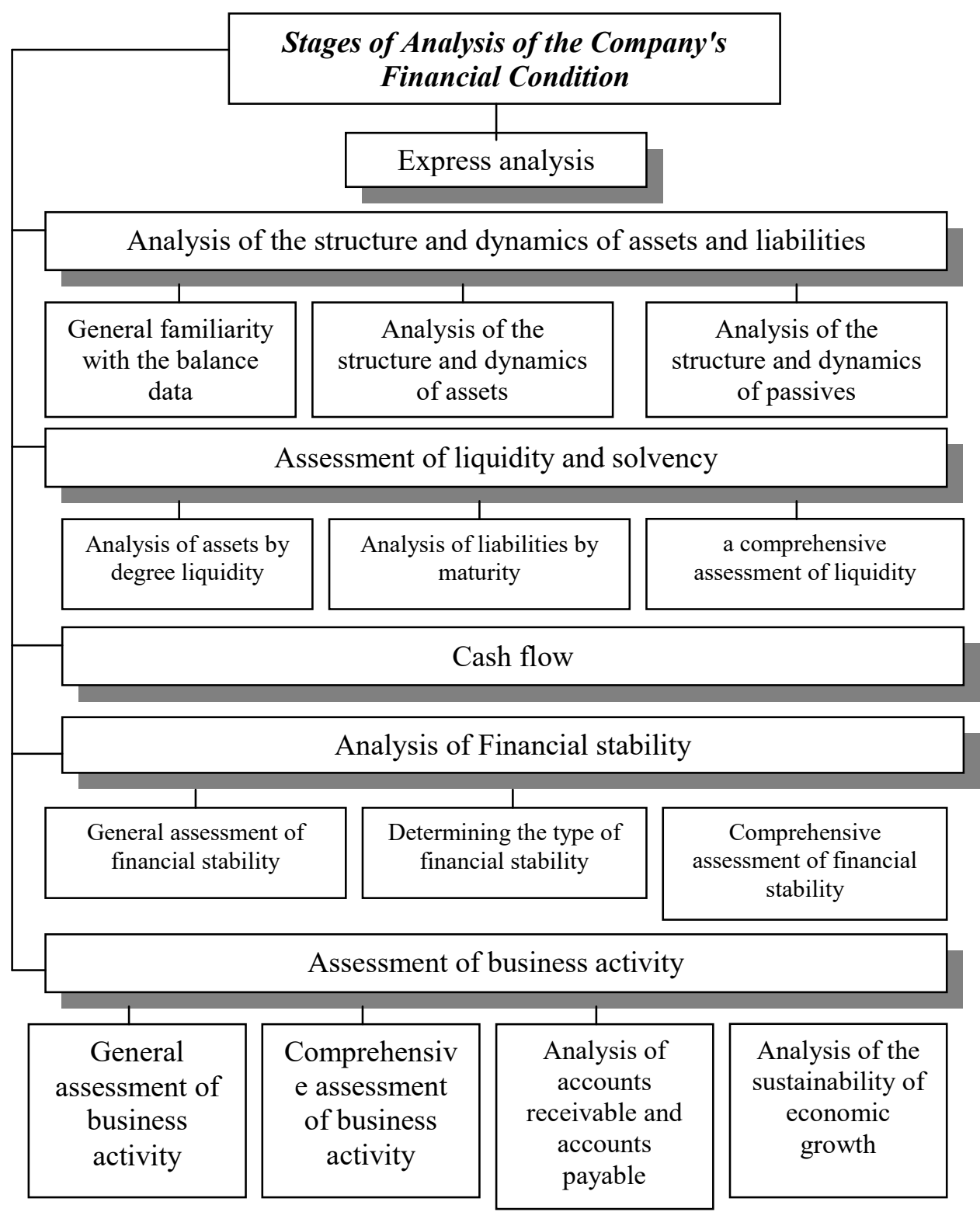

Fig. 2. The main tasks of analyzing the financial condition of the company. Source: Compiled by the authors for [12, p. 216]. 
Creditors are more interested in the solvency of the enterprise, its ability to repay obligations in full and on time. Financial stability of the company (independence from external creditors) also plays an important role for this category of users. This largely affects the business reputation of the company and the conditions that will be laid down in contracts with contractors for the sale and delivery of goods (works, services) [13].

One of the first signals of bankruptcy is insolvency, which means that the company absorbs the resources of creditors and borrowers and generates arrears on mandatory payments. That is, there is an unsatisfactory balance sheet structure, which is defined by World analysts as a certain state of the debtor's property and obligations, when it is not able to ensure timely fulfillment of obligations to creditors at the expense of its property [23, $\mathrm{p}$. 218].

Prospective prognostic estimates of the borrower's financial condition are the result of studying the financial results of its business activities in order to determine their possible values in the future. To identify signs of a crisis in the enterprise, an assessment of the threat of bankruptcy should be carried out on the basis of rapid diagnostics. Express diagnostics of bankruptcy $[1,7,14]$ is a system of regular assessment of crisis parameters of the company's financial development, and is carried out on the basis of its financial statements, using standard analysis algorithms [15, 18, 20, 22]. The simplest is a two-factor model for assessing the probability of bankruptcy of an enterprise (organization) $[9,25, \mathrm{p}$. 81].

It provides for the calculation of a special coefficient $\mathrm{Z}$ and has this formalized form: $\mathrm{Z}$ $=-0.3877-1.0736$ TLR + 0.579 PLM. For LLC Agrocomplex, the total liquidity ratio as of 01.01.19 g. Equal to 1.06. The share of borrowed funds in the total balance sheet liability (QPC) for Agrocomplex LLC for 2019 is 0.388 . The coefficient $Z=-0.3877-1.0736 \times 1.06$ $+0.579 \times 0.388=-1.3$, that is, $Z$ has a negative value, which indicates that the probability of bankruptcy for LLC Agrocomplex is very low. The five-factor Altman model is more reasonable and more common. These coefficients characterize the profitability of capital and its structure from different sides (comprehensively). The Altman index " $Z$ " is calculated using the formula: $Z=3, Z K 1+1,0 \mathrm{~K} 2+0,6 \mathrm{~K} 3+1,4 \mathrm{~K} 4+1,2 \mathrm{~K} 5$. Calculate the Altman index for LLC Agrocomplex according to the company's balance sheet on 01.01.19: $Z=(3.3 \times 0.041)+(1.0 \times 3.486)+(0.6 \times 1.577)+(1.4 \times 0.1)+(1.2 \times 0.021)=$ 4.73 , that is, according to the Altman index, the probability of bankruptcy for LLC Agrocomplex is very low.

Note that the use of a discriminant model for diagnosing the bankruptcy of an enterprise carries a number of threats from the point of view of an adequate definition of its financial condition. For example, when analyzing the financial condition of an enterprise, a situation may arise where for a certain enterprise; some indicators of the discriminant model may be very low compared to their "normal" values, and others - on the contrary, too high, which is also "bad". However, their combination may indicate a stable financial condition of the enterprise, since it is the calculation of a single integral indicator based on all input factors at the same time. The solution to this issue may be to establish a set of rules for making decisions when assessing the financial condition of the enterprise. The calculated credit indicators of LLC Agrocomplex indicate that the company has a low chance of getting a loan or a high risk for creditors.

\section{Conclusions}

Considering the essence of bankruptcy as an economic phenomenon, the following definition can be applied: bankruptcy is a consequence of a deep financial crisis, a system of management measures that has not led to positive results. The financial crisis should be understood as an imbalance in the company's activities and limited opportunities for its 
influence on financial relations. A crisis situation, which has not been overcome by appropriate measures, can lead to a significant imbalance of the economic organism of the enterprise, the inability to provide financial support for its activities, is considered as the bankruptcy of the enterprise. Having considered the main causes of the bankruptcy situation in the enterprise, it should be noted that all these crisis factors operate in a complex, which makes it difficult to eliminate them and eliminate the consequences of their actions. The analysis of financial prerequisites for insolvency and signs of bankruptcy of LLC Agrocomplex showed that the company LLC Agrocomplex has a stable financial condition and a very low level of probability of bankruptcy. LLC Agrocomplex has a negative trend a decline in production. The decrease in total assets occurred: by $40.1 \%$ due to a decrease in non-current assets; by $59.4 \%$ due to a decrease in working capital. The company's liabilities decreased in 2017 as a result of a reduction in its own capital (by 682 thousand UAH., Which is $27.6 \%$ of the total reduction in liabilities), and by reducing the debt capital (in General, by 1678 thousand UAH., Which is $67.8 \%$ of the total reduction in liabilities). Positive growth $(+72.5 \%)$ is the indicator of retained earnings of the company. At the same time, the calculations of real possibilities for restoring solvency indicate that the company has the opportunity to restore its solvency in the next 6 months.

\section{References}

1. E. I. Altman, E. Hotchkiss. Corporate financial distress and bankruptcy: Predict and avoid bankruptcy, analyze and invest in distressed debt. 289 (John Wiley \& Sons, 2010).

2. G. Abuselidze, Asian Economic and Financial Review 3, 11 (2013).

3. G. Abuselidze. Science and studies of accounting and finance: problems and perspectives 12, 1 (2018). doi.org/10.15544/ssaf.2018.01

4. G. Abuselidze, Academy of Strategic Management Journal 18, 4 (2019).

5. G. Abuselidze, Optimality of Tax Policy on the Basis of Comparative Analysis of Income Taxation. European Journal of Sustainable Development 9, 1 (2020). doi.org/10.14207/ejsd.2020.v9n1p272

6. Agency for the prevention of bankruptcy of enterprises and organizations, "Regulations on the procedure for creating and maintaining a single database of enterprises for which bankruptcy proceedings have been initiated". http://zakon5.rada.gov.ua/laws/show/z0835-99.

7. R. Carter, H. V. Auken, Journal of Small Business Management 44, 4 (2006). doi.org/10.1111/j.1540-627X.2006.00187.x

8. Code of Ukraine from bankruptcy procedures. https://zakon.rada.gov.ua/laws/show/2597-19

9. N. Davydenko, H. Skrypnyk; Z. Titenko; O.V. Zhovnirenko, Global Journal of Environmental Science and Management-GJESM. SPECIAL ISSUE, (2019). doi: 10.22034/GJESM.2019.05.SI.22

10. C. G. da Silva, F.V. Vieira, Monetary and Fiscal Policy in the World Economy: Coordination Before and After the Financial Crisis (2014). https://editorialexpress.com/cgibin/conference/download.cgi?db_name=SBE36\&paper_id $=18$

11. F. F. Efimova, The Theory of accounting (IDTU, Zhitomir, 2000).

12. F. F. Efimova, Economic analysis: a textbook (Zhitomir state of emergency Ruta, 2003). 
13. A. P. Gradov, Economic strategy of the company: a textbook( Saint Petersburg, 2000).

14. S. A. Hillegeist, E. K. Keating, D. P. Cram, K. G. Lundstedt, Review of accounting studies 9, 1 (2004). doi:10.1023/B:RAST.0000013627.90884.b7

15. G. Iatridis, International review of financial analysis 19, 3 (2010). doi:10.1016/j.irfa.2010.02.004

16. V. V. Kovalenko, M. V. Suhaniaka, V. I. Fuchedzhy, Anti-crisis financial administration in the system of business entities: assessment methods and tools: monograph (Odesa, 2015).

17. A. P. Kraynik, Financial management (Intellect, 2001).

18. P. Longinidis, M. C. Georgiadis, International journal of production economics 129, 2 (2011). doi:10.1016/j.ijpe.2010.10.018

19. V. S. Lenya, Organization of accounting: Textbook (Moscow, Center for educational literature, 2006).

20. R. Pinsker, P. Wheeler, Journal of Disclosure and Governance 6, 3 (2009). doi:10.1057/jdg.2009.6

21. V. Prokhorova, V. Protsenko, G. Abuselidze, S. Mushnykova, Y. Us, Scientific Bulletin of National Mining University 5 (2019). doi:10.29202/nvngu/2019-5/24

22. T. R. Robinson, International financial statement analysis (John Wiley \& Sons, 2020)

23. Z. E. Shershneva, Strategic management: textbook (Moscow, KNEU, 2004)

24. S. V. Svirko, Organization of accounting in budgetary institutions: Textbook (Moscow, Finance, 2003).

25. V. A. Vasilenko, Anti-Crisis Management: studies. stipend (Moscow, Center for educational literature, 2009). 